\title{
Author Spotlight: Andrew Ofosu
}

\section{Andrew Ofosu ${ }^{1}$}

Accepted: 17 November 2020

(c) The Author(s), under exclusive licence to Springer Science+Business Media, LLC, part of Springer Nature 2021, corrected publication 2021

Andrew Ofosu, MD, MPH is currently the Advanced Endoscopy Fellow at Stanford University, Division of Gastroenterology and Hepatology.

He completed his gastroenterology fellowship at the Brooklyn Hospital in New York and a Transplant Hepatology Fellowship at Thomas Jefferson University Hospital.

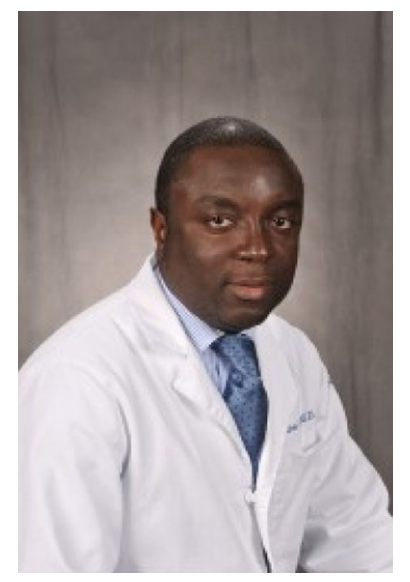

His clinical and research interest includes pancreato-biliary diseases with an emphasis on therapeutic endoscopic ultrasound.

$\mathrm{He}$ is looking forward to pursuing a career in academic advanced endoscopy after completion of his fellowship.

Publisher's Note Springer Nature remains neutral with regard to jurisdictional claims in published maps and institutional affiliations.

Andrew Ofosu

aofosu@stanford.edu

1 Present Address: Division of Gastroenterology and Hepatology, Stanford University, Stanford, USA 